Research Article

\title{
Bond Properties of RAC-Filled Square Steel Tubes after High Temperature
}

\author{
Wanjie Zou, ${ }^{1}$ Jiongfeng Liang $\mathbb{C D}^{2,3}$ Guangwu Zhang $\mathbb{D}^{3},{ }^{3}$ and Haifeng Yang ${ }^{4}$ \\ ${ }^{1}$ College of Civil and Architecture Engineering, Guangxi University of Science and Technology, Liuzhou, China \\ ${ }^{2}$ State Key Laboratory Breeding Base of Nuclear Resources and Environment, East China University of Technology, \\ Nanchang, China \\ ${ }^{3}$ Faculty of Civil \& Architecture Engineering, East China University of Technology, Nanchang, China \\ ${ }^{4}$ College of Civil Engineering and Architecture, Guangxi University, Nanning, China \\ Correspondence should be addressed to Jiongfeng Liang; jiongfeng108@126.com
}

Received 15 July 2019; Revised 3 September 2019; Accepted 13 November 2019; Published 29 November 2019

Academic Editor: Antonio Caggiano

Copyright (c) 2019 Wanjie Zou et al. This is an open access article distributed under the Creative Commons Attribution License, which permits unrestricted use, distribution, and reproduction in any medium, provided the original work is properly cited.

This paper presents the results of an experimental study to investigate the influence of high temperatures on the bond properties between the recycled coarse aggregate (RCA) concrete and square steel tubes. A total of 27 pushout recycled aggregate concrete(RAC-) filled square steel tube specimens are cast and heated under five different temperatures $\left(20^{\circ} \mathrm{C}, 200^{\circ} \mathrm{C}, 400^{\circ} \mathrm{C}, 600^{\circ} \mathrm{C}\right.$, and $800^{\circ} \mathrm{C}$ ) for testing. The main parameters considered in the test are temperature, exposure time of heating, RCA replacement ratio, interface length-to-width ratio, and concrete strength. The experimental results indicate that the bond strength for recycled coarse aggregate concrete and square steel tube increases with increasing temperatures.

\section{Introduction}

The recycling and reuse of waste concrete as recycled aggregates for new concrete is an important sustainable approach in the production of concrete. By using recycled aggregate concrete, it can solve a series of environmental problems including pollutant release, energy consumption, natural resources extraction, and greenhouse gas emissions. Now, most of the research work focus on mechanical properties of recycled coarse aggregate concrete, such as compressive strength, tensile strength, flexural strength, and elastic modulus [1-5]. Durability of recycled coarse aggregate concrete has also been studied by many researchers [6-8]. These studies found that recycled coarse aggregate concrete has lower strength, lower elastic modulus, increased shrinkage, and increased creep. Moreover, the mechanical performance of the members cast with recycled coarse aggregate concrete has been studied [9-14]. Liu et al. [15] provided a new damage model based on experimental load-displacement curves of recycled concrete-filled steel tube (RCFST) and concrete-filled steel tube (CFST). Chen et al. [16] investigated the bond behavior between the steel tube and the recycled aggregate concrete (RAC) and established the theoretical analytical model for interfacial bond shear transmission length. Chen et al. [17] studied the behavior of normal-strength recycled aggregate concretefilled steel tubes under combined loading.

Fire resistance behaviour and design of concrete structures are one of the key issues. A few studies have been made on the residual mechanical properties of recycled aggregate concrete after elevated temperatures or fire such as compressive strength and splitting tensile strength [18-22]. And limited studies on the mechanical performance of RCFST columns after exposure to high temperatures and in fire have been reported. Yang and Hou [23] studied the mechanical behavior of RCFST after exposure to elevated temperatures of $300^{\circ} \mathrm{C}, 600^{\circ} \mathrm{C}$, and $800^{\circ} \mathrm{C}$. It is concluded that the calculated residual strength and residual elastic modulus of RCFST specimens by using the simplified formula for firedamaged normal CFST are generally lower than the experimental results. Li et al. [24] investigated the compressive behaviour of RCFST columns after exposure to high 
temperatures and proposed degradation regression formulas of mechanical properties and deformation behaviors of RCFST columns after exposure to elevated temperatures.

Some effort has been made to study the bond performance of CFST columns. For example, Chen et al. [17] investigated the influence of different values of height-todiameter ratio, diameter-to-thickness ratio, and concrete strengths on the bond-slip behaviour of concrete-filled stainless steel circular hollow section tubes. Tao et al. [25] studied the bond performance between the steel tube and the concrete in concrete-filled steel tubular columns after exposed to ISO 834 standard fire. Chen et al. [16] investigated the bond behavior between the steel tube and the recycled aggregate concrete (RAC) at room temperature, and the theoretical analytical model for interfacial bond shear transmission length was established.

This study aims at investigating some factors that might affect the bond strength in RAC-filled square steel tubes after high temperature such as temperature, exposure time of heating, RCA replacement ratio, interface length-to-width ratio, and concrete strength. The failure mode, bond stressslip curve, and bond strength are discussed in detail.

\section{Experimental Programme}

2.1. Materials Properties. Table 1 provides the design of the concrete mix and its slump, which was designed with varying the RCA replacement ratio (i.e., RCA replaced 0, 50, and $100 \%$ of coarse aggregate in the concrete by weight, respectively). And there were two types of concrete in this study, where the test strength designed were C30 and C40. The recycled aggregate concrete (RAC) mixes were made up of cement, a natural fine aggregate, a natural coarse aggregate, a recycled coarse aggregate, and water $(W)$. Common Portland cement $(C)$ type 32.5R for C30 and type 42.5R for $\mathrm{C} 40$ were used in this study. Used fine aggregates were river sand $(S)$ with a fineness modulus of 2.7 and $0.6 \%$ moisture content. The coarse aggregates used in this study are both natural coarse aggregate (NCA) and recycled coarse aggregate (RCA). The NCA was crushed gravel, with size fraction $5-20 \mathrm{~mm}$. The RCA was obtained from the waste concrete brought from the reclamation depot in Nanchang, PR China, which was in the range 5-20 mm. Figure 1 shows the grading curve of crushed stone and coarse glass aggregate. The physical properties of RCA are shown in Table 2. The yield strength, ultimate tensile strength, and modulus of elasticity of square steel tubes (Q235) are $273 \mathrm{MPa}, 375 \mathrm{MPa}$, and $201 \mathrm{GPa}$, which were used in these pushout tests.

2.2. Specimen Design. A total of 27 square recycled aggregate concrete-filled steel tube (SRACFST) pushout specimens were prepared, among which three of them were unheated at ambient temperature (i.e., $20^{\circ} \mathrm{C}$ ) and twenty-four were heated. The main variables investigated in the test were (a) temperature $T\left(T=20^{\circ} \mathrm{C}, 200^{\circ} \mathrm{C}, 400^{\circ} \mathrm{C}, 600^{\circ} \mathrm{C}\right.$, and $\left.800^{\circ} \mathrm{C}\right)$, (b) exposure period $t(t=30 \mathrm{~min}, 60 \mathrm{~min}$, and $120 \mathrm{~min})$, (c) RCA replacement ratio $r(r=0 \%, 50 \%$, and $100 \%)$, (d) concrete strength (C30 and C40), and (e) interface length-todiameter ratio $\left(L_{e} / B=2.2\right.$ and 3.4 , where $L_{e}$ is the length of the steel-concrete interface and $B$ is the width of a square tube). Cold-formed steel tubes were used in the construction of all specimens. The steel tubes were cut into the required lengths. And then RAC was poured into each steel tube layer by layer and vibrated by a poker vibrator. Specifically, RCA replacement percentage refers to the quality percentage of RCA in all the coarse aggregates. Details of the SRACFST pushout specimens are presented in Table 3. At the same time, three concrete cubes with a dimension of $150 \mathrm{~mm} \times 150 \mathrm{~mm} \times 150 \mathrm{~mm}$ were cast of each concrete mix. The compressive cube strength fcu at 28 days of recycled aggregate concrete (RAC) is shown in Table 1 .

2.3. Heat Treatment. SRACFST specimens were heated by exposing them to heat in a high-capacity electrical furnace with a maximum heating temperature of $1200^{\circ} \mathrm{C}$. The heating rate was $50^{\circ} \mathrm{C} / \mathrm{min}$. When the temperature was increased to reach the required temperature level of $200^{\circ} \mathrm{C}$, $400^{\circ} \mathrm{C}, 600^{\circ} \mathrm{C}$, and $800^{\circ} \mathrm{C}$, respectively, it maintained at this level for the required period ( $30 \mathrm{~min}, 60 \mathrm{~min}$, or $120 \mathrm{~min}$ ). The measured temperature was provided and showed by the electrical furnace. After heat treatment, the specimens were cooled at ambient temperature before testing. Also unheated SRACFST specimens were subjected to ambient temperature (i.e., $20^{\circ} \mathrm{C}$ ) and tested for comparing with the heated specimens.

2.4. Testing. The loading setup for the pushout test was a YAW-3000 microcomputer-controlled electrohydraulic servo tester, as shown in Figure 2. The pushout SRACFST specimens were set up vertically with the air gap at the bottom of the testing machine. A layer of sand was spread on the top surface of the SRACFST specimens. A steel block, which had a slightly smaller cross section than that of the inside diameter of the steel tube, was placed on the top of the SRACFST specimens. This assured the load was applied only on the recycled aggregate concrete core and allowed the recycled aggregate concrete core to be pushed out during testing. All specimens were tested under a displacement control rate of $0.5^{\circ} \mathrm{mm} / \mathrm{min}$. The linear variable displacement transducer (LVDT) was used to measure the relative slip between the steel tube and the recycled aggregate concrete core. When the load showed little change with the increase in the slip, the test was terminated.

\section{Results and Discussion}

3.1. Test Observations and Results. During the testing, there was no visible change in appearance for all specimens except for the slip occurred between the RCA concrete core and the square steel tube. At the beginning of the experiment, there was not any evident slip observed between the RCA concrete core and the square steel tube. As the load increased, there was a tiny slip appearance at the free end and the slip developed slowly. And then the slip developed more rapidly with the increase of the load. When the load was close to the 
TABLE 1: Mix proportion of the recycled coarse aggregate concrete.

\begin{tabular}{|c|c|c|c|c|c|c|c|c|}
\hline Concrete type & $r(\%)$ & RCA $\left(\mathrm{kg} \cdot \mathrm{m}^{-3}\right)$ & $C\left(\mathrm{~kg} \cdot \mathrm{m}^{-3}\right)$ & $S\left(\mathrm{~kg} \cdot \mathrm{m}^{-3}\right)$ & NCA $\left(\mathrm{kg} \cdot \mathrm{m}^{-3}\right)$ & $W\left(\mathrm{~kg} \cdot \mathrm{m}^{-3}\right)$ & Slump $(\mathrm{mm})$ & $f_{\mathrm{cu}}(\mathrm{MPa})$ \\
\hline \multirow{3}{*}{ C30 } & 0 & 0 & 513 & 474 & 1218 & 195 & 73 & 35.5 \\
\hline & 50 & 609 & 513 & 474 & 609 & 195 & 71 & 33.2 \\
\hline & 100 & 1218 & 513 & 474 & 0 & 195 & 69 & 31.1 \\
\hline \multirow{3}{*}{ C40 } & 0 & 0 & 454 & 595 & 1152 & 200 & 65 & 48.4 \\
\hline & 50 & 576 & 454 & 595 & 576 & 200 & 63 & 45.2 \\
\hline & 100 & 1152 & 454 & 595 & 0 & 200 & 62 & 40.3 \\
\hline
\end{tabular}

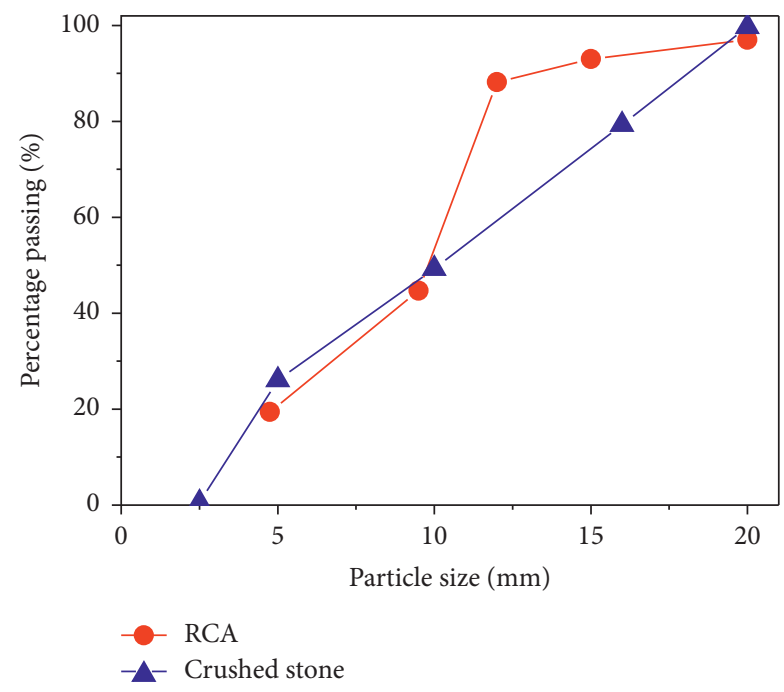

Figure 1: Grading curves of crushed stone and RCA.

TABle 2: Physical properties of RCA and NCA.

\begin{tabular}{lcccccc}
\hline $\begin{array}{l}\text { Coarse } \\
\text { aggregate }\end{array}$ & $\begin{array}{c}\text { Grading } \\
(\mathrm{mm})\end{array}$ & $\begin{array}{c}\text { Bulk density } \\
\left(\mathrm{kg} / \mathrm{m}^{3}\right)\end{array}$ & $\begin{array}{c}\text { Apparent density } \\
\left(\mathrm{kg} / \mathrm{m}^{3}\right)\end{array}$ & $\begin{array}{c}\text { Water absorption } \\
(\%)\end{array}$ & $\begin{array}{c}\text { Silt content } \\
(\%)\end{array}$ & $\begin{array}{c}\text { Crushing value } \\
(\%)\end{array}$ \\
\hline RCA & $5-20$ & 1385 & 2490 & 8.47 & 5.5 & 13.2 \\
NCA & $5-20$ & 1495 & 2752 & 0.8 & 4.2 & 5.2 \\
\hline
\end{tabular}

ultimate load, a sudden loud noise could be heard. After the ultimate load, the RCA concrete core was gradually pushed downward through the square steel tube. A visible gap around the entire perimeter was observed at the loading end, and there was no local bucking observed on the square steel tube when the pushout specimens failed. The typical bond failure is shown in Figure 3. The experimental results of 27 pushout specimens, including peak bond stress $\tau_{u}$ and unloaded end slip $S_{u}$, are summarized in Table 3. The following equation was used to calculate the value of the bond strength:

$$
\tau_{u}=\frac{P_{u}}{A},
$$

where $\tau_{u}$ is the peak bond stress between the concrete and the steel tube which is also termed as the bond strength, $P_{u}$ is the peak load, and $A$ is the contact area along the embedment length.

3.2. Bond Stress versus Slip Curves. Figure 4 shows the typical bond stress $(\tau)$ versus slip $(s)$ curves of the pushout specimens. All the curves experienced the following three stages: adhesion stage, microinterlocking stage, and friction stage. In the adhesion stage, there was no obvious observable slip, and the slope of the curve was linear. The stiffness shown by the bond stress-slip was high. The applied load was primarily resisted by the chemical adhesion between the recycled aggregate concrete and the square steel tube. And then, the slope of the curves decreased as the load increased. The slip began to grow. That was, the adhesion gradually decreased and the curves entered the microinterlocking stage. And the microinterlocking was caused by the surface roughness of the square steel tube and broke when the recycled aggregate concrete interface reached the compressive crushing strain of the recycled aggregate concrete. After peak load, the bond stress-slip curve was descending or almost horizontal and the slip increased. When the curves entered the friction stage, the chemical adhesion was completely destroyed. And as shown in the figure, the pushout specimens with high RCA replacement exhibited a longer chemical adhesion stage than those specimens with low RCA replacement at the same temperature. This might be because increasing 
TABLE 3: Summary of test specimens and results.

\begin{tabular}{|c|c|c|c|c|c|c|c|c|}
\hline No. & $B \times t_{s} \times L(\mathrm{~mm})$ & $T\left(0^{\circ} \mathrm{C}\right)$ & $t(\min )$ & $r(\%)$ & Concrete type & $L_{e} / B$ & $\tau_{u}(\mathrm{MPa})$ & $S_{u}(\mathrm{~mm})$ \\
\hline$\overline{S 1}$ & $120 \times 3 \times 410$ & 600 & 120 & 0 & C30 & 3.4 & 1.22 & 0.74 \\
\hline S2 & $120 \times 3 \times 410$ & 600 & 120 & 50 & $\mathrm{C} 30$ & 3.4 & 1.35 & 0.64 \\
\hline S3 & $120 \times 3 \times 410$ & 600 & 120 & 100 & $\mathrm{C} 30$ & 3.4 & 1.42 & 0.73 \\
\hline S4 & $120 \times 3 \times 410$ & 600 & 120 & 0 & $\mathrm{C} 40$ & 3.4 & 1.30 & 0.52 \\
\hline S5 & $120 \times 3 \times 410$ & 600 & 120 & 50 & $\mathrm{C} 40$ & 3.4 & 1.40 & 0.54 \\
\hline S6 & $120 \times 3 \times 410$ & 600 & 120 & 100 & $\mathrm{C} 40$ & 3.4 & 1.52 & 0.77 \\
\hline S7 & $120 \times 3 \times 260$ & 600 & 120 & 0 & C30 & 2.2 & 1.15 & 0.64 \\
\hline S8 & $120 \times 3 \times 260$ & 600 & 120 & 50 & C30 & 2.2 & 1.28 & 0.82 \\
\hline S9 & $120 \times 3 \times 260$ & 600 & 120 & 100 & C30 & 2.2 & 1.37 & 1.54 \\
\hline S10 & $120 \times 3 \times 260$ & 20 & 0 & 0 & C30 & 2.2 & 0.47 & 0.39 \\
\hline $\mathrm{S} 11$ & $120 \times 3 \times 260$ & 200 & 120 & 0 & C30 & 2.2 & 0.69 & 0.64 \\
\hline $\mathrm{S} 12$ & $120 \times 3 \times 260$ & 400 & 120 & 0 & C30 & 2.2 & 0.88 & 0.52 \\
\hline $\mathrm{S} 13$ & $120 \times 3 \times 260$ & 800 & 120 & 0 & C30 & 2.2 & 1.60 & 2.83 \\
\hline S14 & $120 \times 3 \times 260$ & 20 & 0 & 50 & C30 & 2.2 & 0.52 & 0.51 \\
\hline $\mathrm{S} 15$ & $120 \times 3 \times 260$ & 200 & 120 & 50 & C30 & 2.2 & 0.79 & 0.50 \\
\hline S16 & $120 \times 3 \times 260$ & 400 & 120 & 50 & C30 & 2.2 & 0.95 & 0.48 \\
\hline S17 & $120 \times 3 \times 260$ & 800 & 120 & 50 & C30 & 2.2 & 1.72 & 2.64 \\
\hline S18 & $120 \times 3 \times 260$ & 20 & 0 & 100 & $\mathrm{C} 30$ & 2.2 & 0.54 & 0.58 \\
\hline S19 & $120 \times 3 \times 260$ & 200 & 120 & 100 & C30 & 2.2 & 0.89 & 0.67 \\
\hline $\mathrm{S} 20$ & $120 \times 3 \times 260$ & 400 & 120 & 100 & C30 & 2.2 & 1.06 & 1.45 \\
\hline $\mathrm{S} 21$ & $120 \times 3 \times 260$ & 800 & 120 & 100 & $\mathrm{C} 30$ & 2.2 & 1.91 & 2.17 \\
\hline $\mathrm{S} 22$ & $120 \times 3 \times 260$ & 600 & 30 & 0 & C30 & 2.2 & 0.81 & 0.34 \\
\hline $\mathrm{S} 23$ & $120 \times 3 \times 260$ & 600 & 60 & 0 & $\mathrm{C} 30$ & 2.2 & 0.98 & 0.56 \\
\hline S24 & $120 \times 3 \times 260$ & 600 & 30 & 50 & C30 & 2.2 & 0.89 & 0.55 \\
\hline $\mathrm{S} 25$ & $120 \times 3 \times 260$ & 600 & 60 & 50 & $\mathrm{C} 30$ & 2.2 & 1.11 & 0.65 \\
\hline $\mathrm{S} 26$ & $120 \times 3 \times 260$ & 600 & 30 & 100 & C30 & 2.2 & 1.12 & 0.89 \\
\hline S27 & $120 \times 3 \times 260$ & 600 & 60 & 100 & $\mathrm{C} 30$ & 2.2 & 1.21 & 1.08 \\
\hline
\end{tabular}
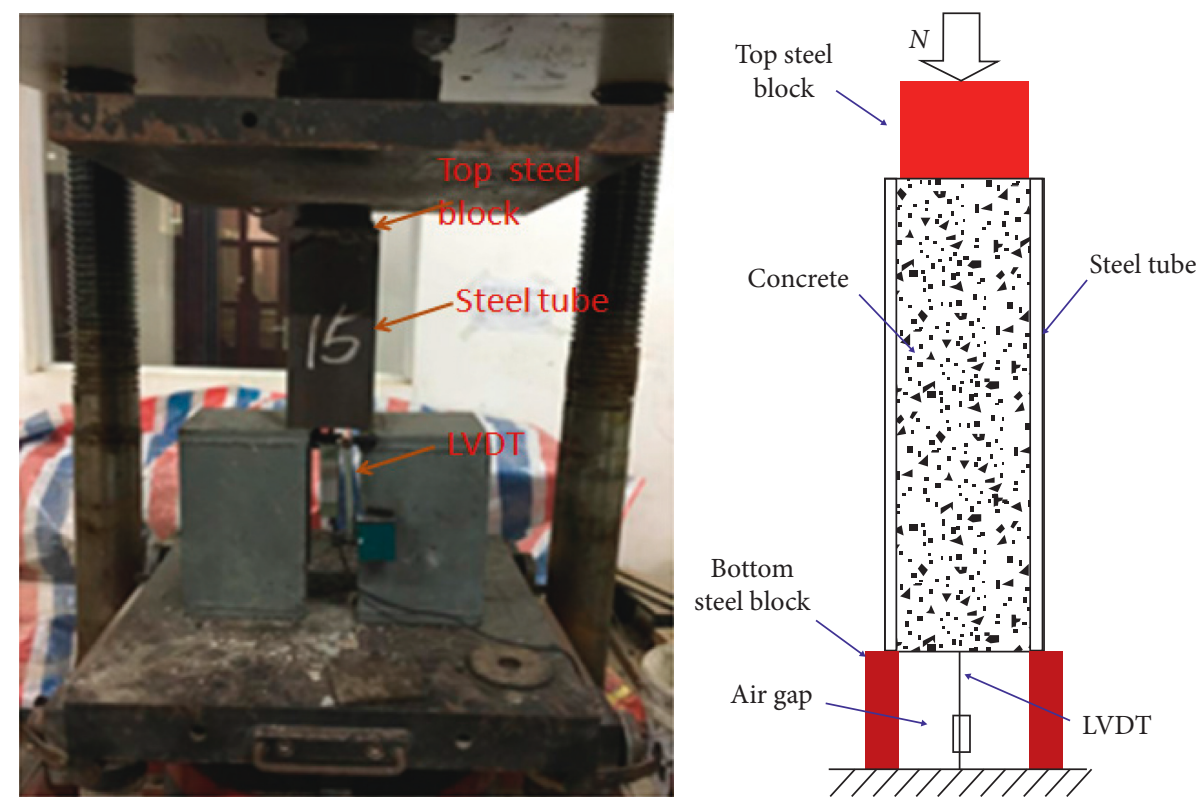

Figure 2: Test setup.

shrinkage of RAC reduced the contact area between the concrete core and the steel tube, thereby lengthening the chemical adhesion. The heated pushout specimens exhibited a longer chemical adhesion stage than those of the unheated specimens. The chemical adhesion stage of the bond stress versus slip curves increased with the increase in exposure time.

\subsection{Bond Strength}

3.3.1. Effect of Temperature on the Bond Strength. The effect of temperature on the bond strength of the square steel tube pullout specimens is shown in Figure 5. It is shown that the bond strength between the square steel tube and the recycled aggregate concrete increased with an increase in the 


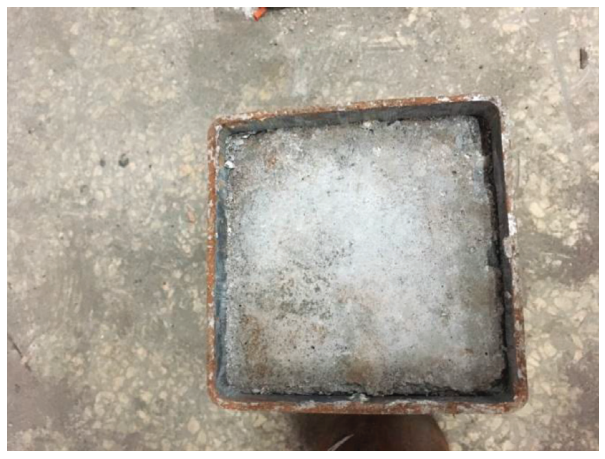

Figure 3: Failure mode.
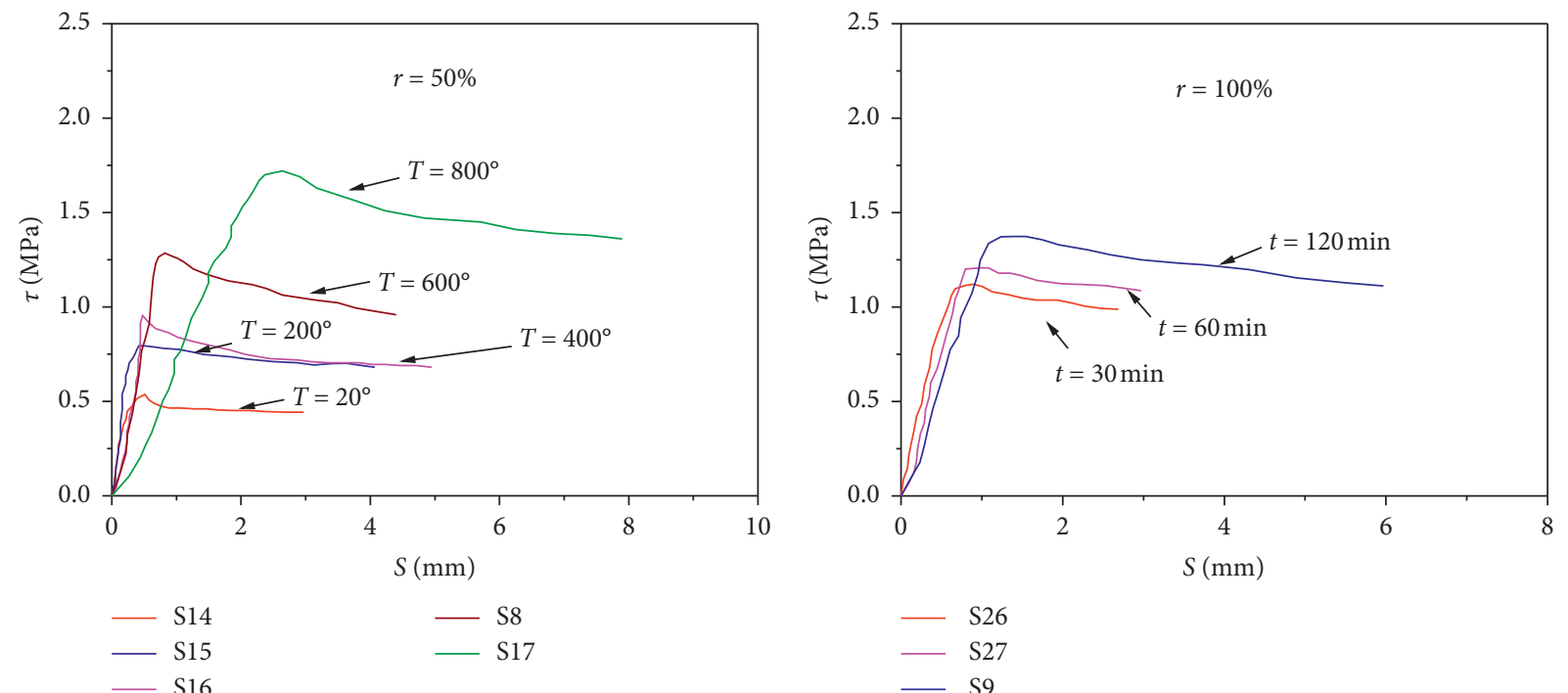

— S26

- S27

- 59

(a)

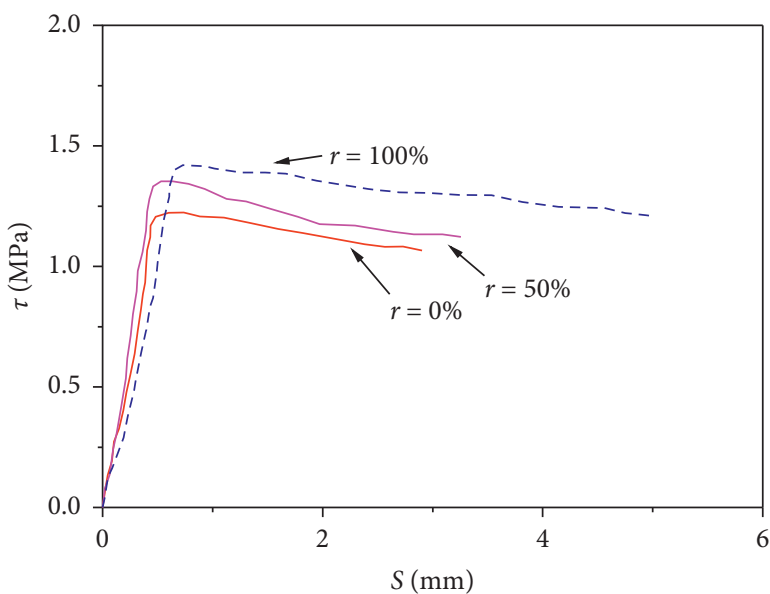

(b)

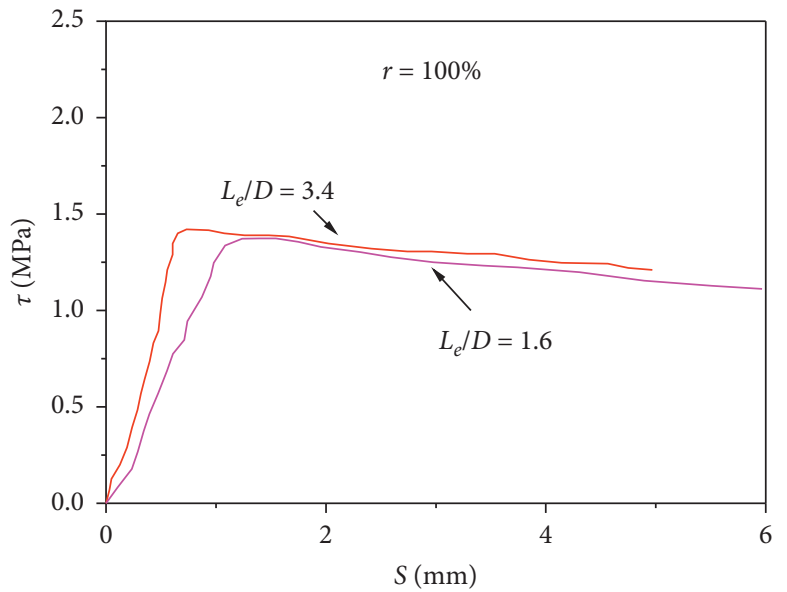

$\mathrm{S} 1$
$\mathrm{~S} 2$

- S3

-. $\mathrm{S} 3$

(c)

Figure 4: Continued. 


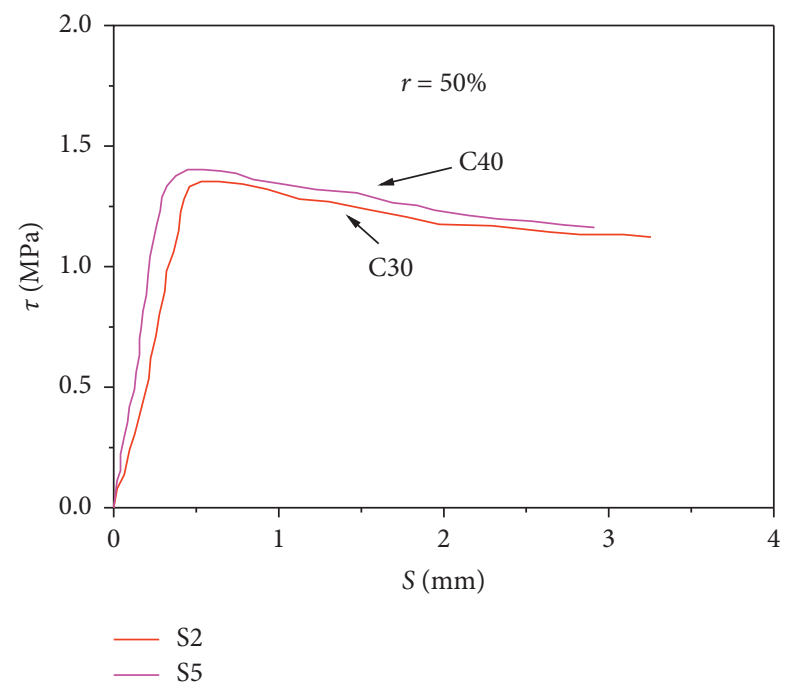

(e)

FIgURE 4: Typical bond stress-slip curves: effect of (a) temperature, (b) exposure time, (c) RCA replacement ratio, (d) interface length-towidth ratio, and (e) concrete strength.

temperature. It reached a value of $0.69 \mathrm{MPa}, 0.79 \mathrm{MPa}$, and $0.89 \mathrm{MPa}$ for $\mathrm{S} 11, \mathrm{~S} 15$, and $\mathrm{S} 19$, respectively, after exposure to $200^{\circ} \mathrm{C}$. After exposure to $400^{\circ} \mathrm{C}, 600^{\circ} \mathrm{C}$, and $800^{\circ} \mathrm{C}$, the increases in the bond strength of the square steel tube pushout specimens with $0 \%$ replacement percentage of RCA were approximately $86.4 \%, 145.3 \%$, and $241.3 \%$ than that of the unheated square steel tube pushout specimens, respectively. For the square steel tube pushout specimens with $50 \%$ replacement percentage of RCA, the increases in bond strength were $83.5 \%, 146.7 \%$, and $230.0 \%$, respectively. For the square steel tube pushout specimens with $100 \%$ replacement percentage of RCA, the increases in bond strength were $93.3 \%, 149.6 \%$, and $247.5 \%$, respectively.

\subsubsection{Effect of Exposure Time on the Bond Strength.} Figure 6 shows the effect of exposure time on the bond strength between the square steel tube and the recycled aggregate concrete. It can be seen that the bond strength of the square steel tube pushout specimens rose with the increase in exposure time. For the square steel tube pushout specimens with $0 \%$ replacement percentage of RCA, the bond strength increased by $20.1 \%$ and $41.9 \%$ after an exposure time of $60 \mathrm{~min}$ and $120 \mathrm{~min}$, respectively. For the square steel tube pushout specimens with $50 \%$ replacement percentage of RCA, the bond strength increased by $24.5 \%$ and $43.5 \%$ after an exposure time of $60 \mathrm{~min}$ and $120 \mathrm{~min}$, respectively. For the square steel tube pushout specimens with 100\% replacement percentage of RCA, the bond strength increased by $7.8 \%$ and $22.6 \%$ after an exposure time of $60 \mathrm{~min}$ and $120 \mathrm{~min}$, respectively. These may be attributed to the following reason: after exposure to the same high temperature, the decrease in the strength of the RAC was greater than that of the steel tube and it caused the increase in the constraining effect [24].

3.3.3. Effect of RCA Replacement Ratio on the Bond Strength. The effect of RCA replacement ratio on the bond strength between the square steel tube and the recycled aggregate concrete is shown in Figure 7. It is shown that the bond

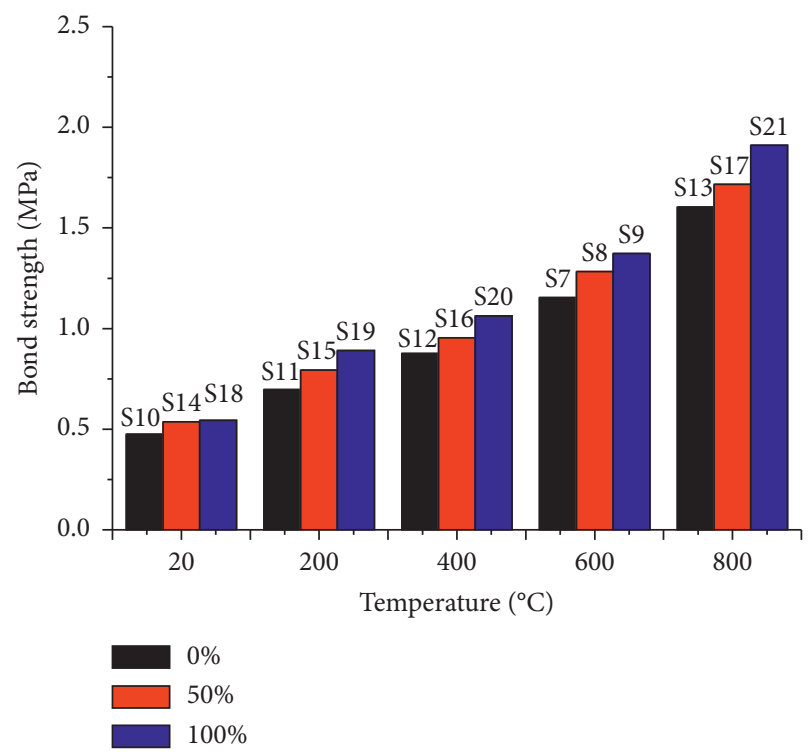

Figure 5: Effect of temperature on bond strength.

strength of the pushout specimens with RCA is larger than those specimens with NCA at the same temperature. This reason may be attributed to the weaker fire resistance of recycled aggregate concrete compared to natural aggregate concrete, especially at elevated temperatures [24].

\subsubsection{Effect of Interface Length-to-Width Ratio on the Bond} Strength. The effect of interface length-to-width ratio on the bond strength between the square steel tube and the recycled aggregate concrete is shown in Figure 8. It can be seen that the bond strength of the heated square steel tube pushout specimens with larger length-to-width ratio was much higher than that of the specimens with lower length-to-width ratio. In other 


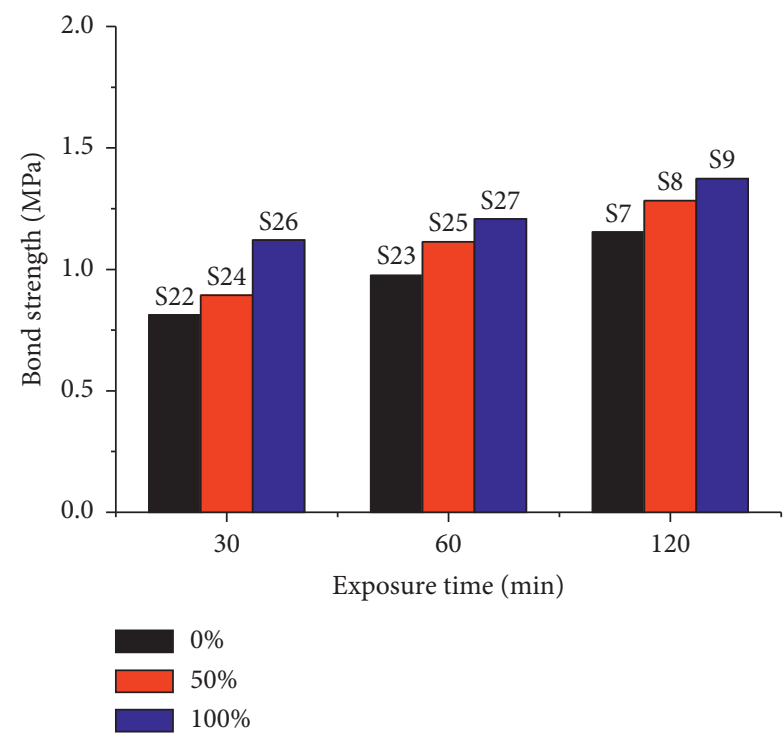

Figure 6: Effect of exposure time on bond strength.

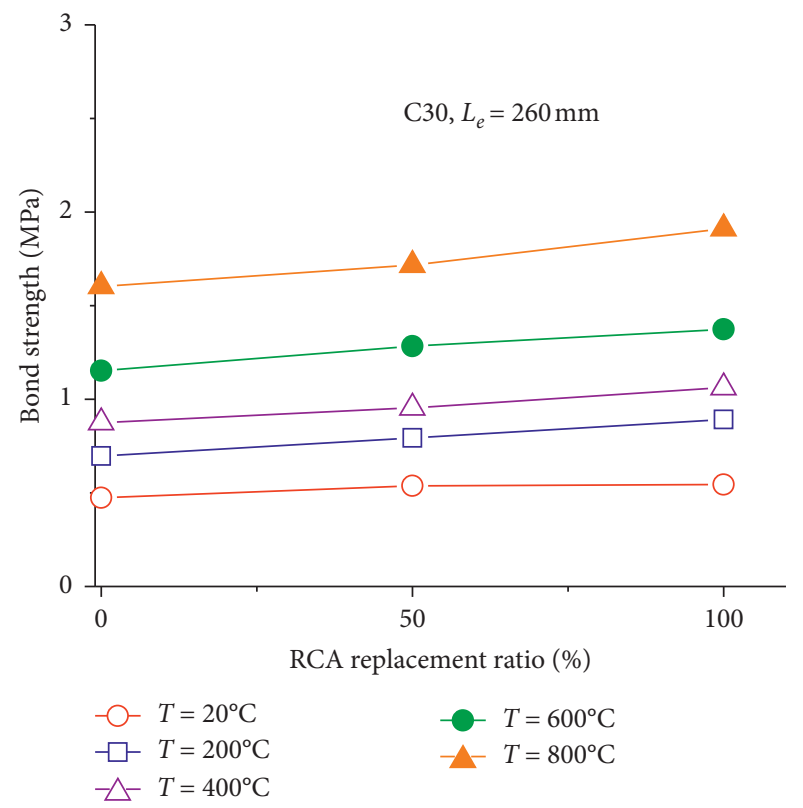

FIgURE 7: Effect of RCA replacement ratio on bond strength.

words, the bond strength increased with increasing interface length-to-width ratio. When increasing the interface length-towidth ratio from 1.6 to 3.4 , it leaded to the increase in the bond strength from 1.15 $\mathrm{MPa}$ to $1.22 \mathrm{MPa}$ for the square steel tube pushout specimens with $0 \%$ replacement percentage of RCA. And it increased by $5.5 \%$ and $3.6 \%$ bond strength for the square steel tube pushout specimens with $50 \%$ replacement percentage of RCA and that of the pushout specimens with $100 \%$ replacement percentage of RCA, respectively.

3.3.5. Effect of Concrete Strength on the Bond Strength. The effect of concrete strength on the bond strength between the square steel tube and the recycled aggregate concrete is shown in Figure 9. It can be seen that the bond

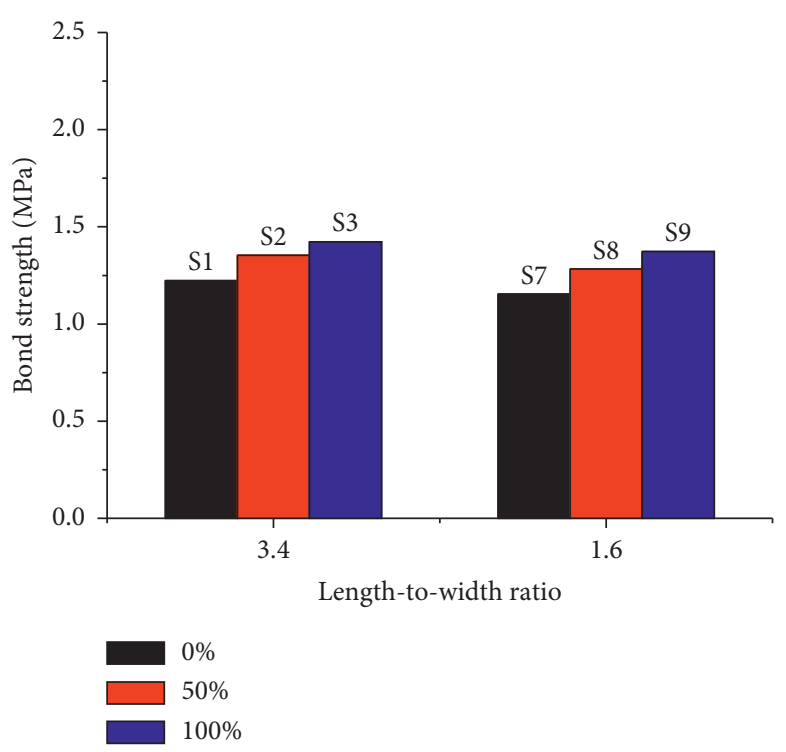

FIGURE 8: Effect of length-to-width ratio on bond strength.

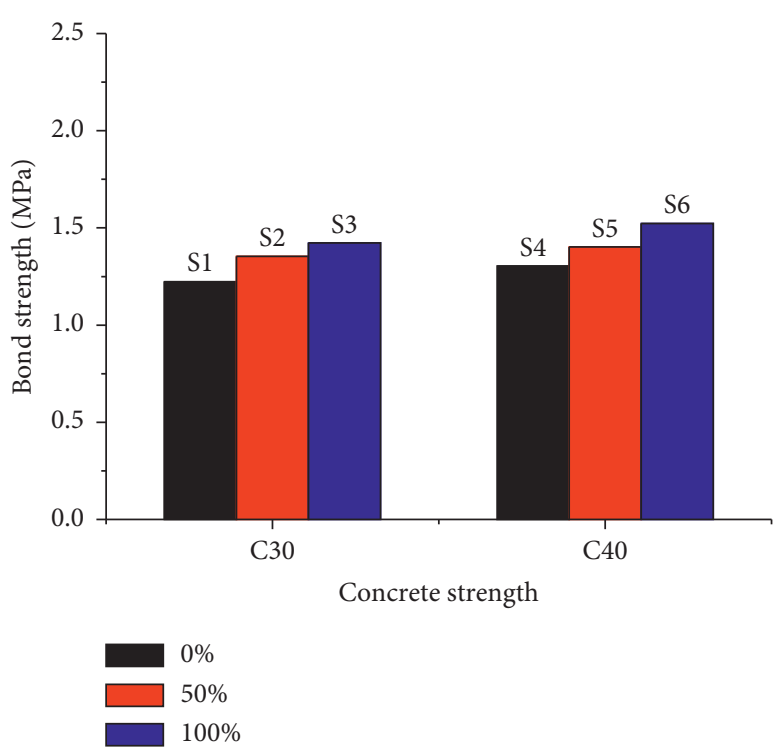

Figure 9: Effect of concrete strength on bond strength.

strength between the square steel tube and the recycled aggregate concrete increased as the concrete strength increased. The bond strength of test specimens with an RCA replacement ratio of $0 \%$ was $1.22 \mathrm{MPa}$ for the C30 specimen (S1) and 1.30 MPa for the C40 specimen (S4). The bond strength of test specimens with an RCA replacement ratio of $50 \%$ was $1.35 \mathrm{MPa}$ for the C30 specimen (S2) and $1.40 \mathrm{MPa}$ for the C40 specimen (S5). The bond strength of test specimens with an RCA replacement ratio of $100 \%$ was $1.42 \mathrm{MPa}$ for the C30 specimen (S3) and $1.52 \mathrm{MPa}$ for the $\mathrm{C} 40$ specimen (S6). This may be because the adhesion resistance and mechanical interlock at the interface between the steel tube and the recycled aggregate concrete increased when the concrete strength increased. 


\section{Findings and Conclusions}

The utilization of the recycled aggregate concrete would be an ideal choice for sustainable construction. An experimental program of bond behavior between the recycled coarse aggregate concrete and the square steel tube is discussed in this paper. Based on the experimental results, the following conclusions can be drawn:

(i) The pushout test results of RAC-filled square steel tubes after high temperature showed that their bond failure mode was similar to normal concrete-filled square steel tubes

(ii) The bond strength of heated RAC-filled square steel tubes was usually higher than that of RAC-filled square steel tubes at ambient temperature

(iii) The shape of bond stress-slip curves for the pushout specimens was affected by temperature level to some extent

(iv) The postheating bond strength of RAC-filled square steel tubes increased with the increasing exposure time of heating, RCA replacement ratio, interface length-to-width ratio, and concrete strength

Further research is needed to study on the model for bond stress-slippage according to more test results.

\section{Data Availability}

The data used to support the findings of this study are included within the article.

\section{Conflicts of Interest}

The authors declare that they have no conflicts of interest regarding the publication of this paper.

\section{Acknowledgments}

This work was supported by the Chinese National Natural Science Foundation (no. 51868001), the Natural Science Foundation of Jiangxi Province for Distinguished Young Scholars (no. 20162BCB23051), the Natural Science Foundation of Jiangxi Province (no. 20171BAB206053), and the Hundred People Voyage Project of Jiangxi Province, which are gratefully acknowledged.

\section{References}

[1] V. Abreu, L. Evangelista, and J. de Brito, "The effect of multirecycling on the mechanical performance of coarse recycled aggregates concrete," Construction and Building Materials, vol. 188, pp. 480-489, 2018.

[2] M. J. McGinnis, M. Davis, A. de la Rosa, B. D. Weldon, and Y. C. Kurama, "Strength and stiffness of concrete with recycled concrete aggregates," Construction and Building Materials, vol. 154, pp. 258-269, 2017.

[3] A. Akhtar and A. K. Sarmah, "Strength improvement of recycled aggregate concrete through silicon rich char derived from organic waste," Journal of Cleaner Production, vol. 196, pp. 411-423, 2018.
[4] J. Xiao, W. Li, Y. Fan, and X. Huang, "An overview of study on recycled aggregate concrete in China (1996-2011)," Construction and Building Materials, vol. 31, pp. 364-383, 2012.

[5] C. Ngohpok, V. Sata, T. Satiennam, P. Klungboonkrong, and P. Chindaprasirt, "Mechanical properties, thermal conductivity, and sound absorption of pervious concrete containing recycled concrete and bottom ash aggregates," KSCE Journal of Civil Engineering, vol. 22, no. 4, pp. 1369-1376, 2018.

[6] D. Xuan, B. Zhan, and C. S. Poon, "Durability of recycled aggregate concrete prepared with carbonated recycled concrete aggregates," Cement and Concrete Composites, vol. 84, pp. 214-221, 2017.

[7] J. Thomas, N. N. Thaickavil, and P. M. Wilson, "Strength and durability of concrete containing recycled concrete aggregates," Journal of Building Engineering, vol. 19, pp. 349-365, 2018.

[8] P. Saravanakumar and G. Dhinakaran, "Durability characteristics of recycled aggregate concrete," Structural Engineering and Mechanics, vol. 47, no. 5, pp. 701-711, 2013.

[9] J. Chen, X. Liu, H. Liu, and L. Zeng, "Axial compression behavior of circular recycled concrete-filled steel tubular short columns reinforced by silica fume and steel fiber," Steel and Composite Structures, vol. 27, no. 2, pp. 193-200, 2018.

[10] K. N. Rahal and Y. T. Alrefaei, "Shear strength of recycled aggregate concrete beams containing stirrups," Construction and Building Materials, vol. 191, pp. 866-876, 2018.

[11] Y.-C. Tang, L.-J. Li, W.-X. Feng, F. Liu, and M. Zhu, "Study of seismic behavior of recycled aggregate concrete-filled steel tubular columns," Journal of Constructional Steel Research, vol. 148, pp. 1-15, 2018.

[12] M. R. Brandes and Y. C. Kurama, "Behavior of shear-critical prestressed concrete beams with recycled concrete aggregates under ultimate loads," Engineering Structures, vol. 165, pp. 237-246, 2018.

[13] Z. Chen, C. Jing, J. Xu, and X. Zhang, "Seismic performance of recycled concrete-filled square steel tube columns," Earthquake Engineering and Engineering Vibration, vol. 16, no. 1, pp. 119-130, 2017.

[14] W.-C. Choi and H.-D. Yun, "Compressive behavior of reinforced concrete columns with recycled aggregate under uniaxial loading," Engineering Structures, vol. 41, pp. 285-293, 2012.

[15] Y. Liu, X. Zha, and G. Gong, "Study on recycled-concretefilled steel tube and recycled concrete based on damage mechanics," Journal of Constructional Steel Research, vol. 71, pp. 143-148, 2012.

[16] Z. Chen, J. Xu, Y. Liang, and Y. Su, "Bond behaviors of shape steel embedded in recycled aggregate concrete and recycled aggregate concrete filled in steel tubes," Steel and Composite Structures, vol. 17, no. 6, pp. 929-949, 2014.

[17] Y. Chen, R. Feng, Y. Shao, and X. Zhang, "Bond-slip behaviour of concrete-filled stainless steel circular hollow section tubes," Journal of Constructional Steel Research, vol. 130, pp. 248-263, 2017.

[18] N. K. Bui, T. Satomi, and H. Takahashi, "Effect of mineral admixtures on properties of recycled aggregate concrete at high temperature," Construction and Building Materials, vol. 184, pp. 361-373, 2018.

[19] J. F. Liang, E. Wang, C. F. He, and P. Hu, "Mechanical behavior of recycled fine aggregate concrete after high temperature," Structural Engineering \& Mechanics, vol. 65, no. 3, pp. 343-348, 2018.

[20] J. F. Liang, Z. P. Yang, P. H. Yi, and J. B. Wang, "Stress-strain relationship for recycled aggregate concrete after exposure to 
elevated temperatures," Computers and Concrete, vol. 19, no. 6, pp. 609-615, 2018.

[21] W. Khaliq and Taimur, "Mechanical and physical response of recycled aggregates high-strength concrete at elevated temperatures," Fire Safety Journal, vol. 96, pp. 203-214, 2018.

[22] D. Cree, M. Green, and A. Noumowé, "Residual strength of concrete containing recycled materials after exposure to fire: a review," Construction and Building Materials, vol. 45, pp. 208-223, 2013.

[23] Y. F. Yang and R. Hou, "Experimental behaviour of RACFST stub columns after exposed to high temperatures," ThinWalled Structures, vol. 59, no. 4, pp. 1-10, 2012.

[24] W. Li, Z. Luo, Z. Tao, W. H. Duan, and S. P. Shah, "Mechanical behavior of recycled aggregate concrete-filled steel tube stub columns after exposure to elevated temperatures," Construction and Building Materials, vol. 146, pp. 571-581, 2017.

[25] Z. Tao, L.-H. Han, B. Uy, and X. Chen, "Post-fire bond between the steel tube and concrete in concrete-filled steel tubular columns," Journal of Constructional Steel Research, vol. 67, no. 3, pp. 484-496, 2011. 


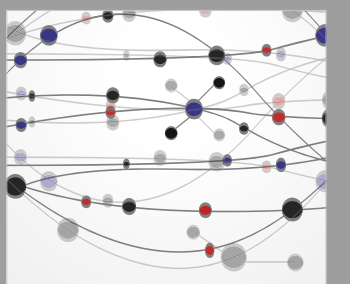

The Scientific World Journal
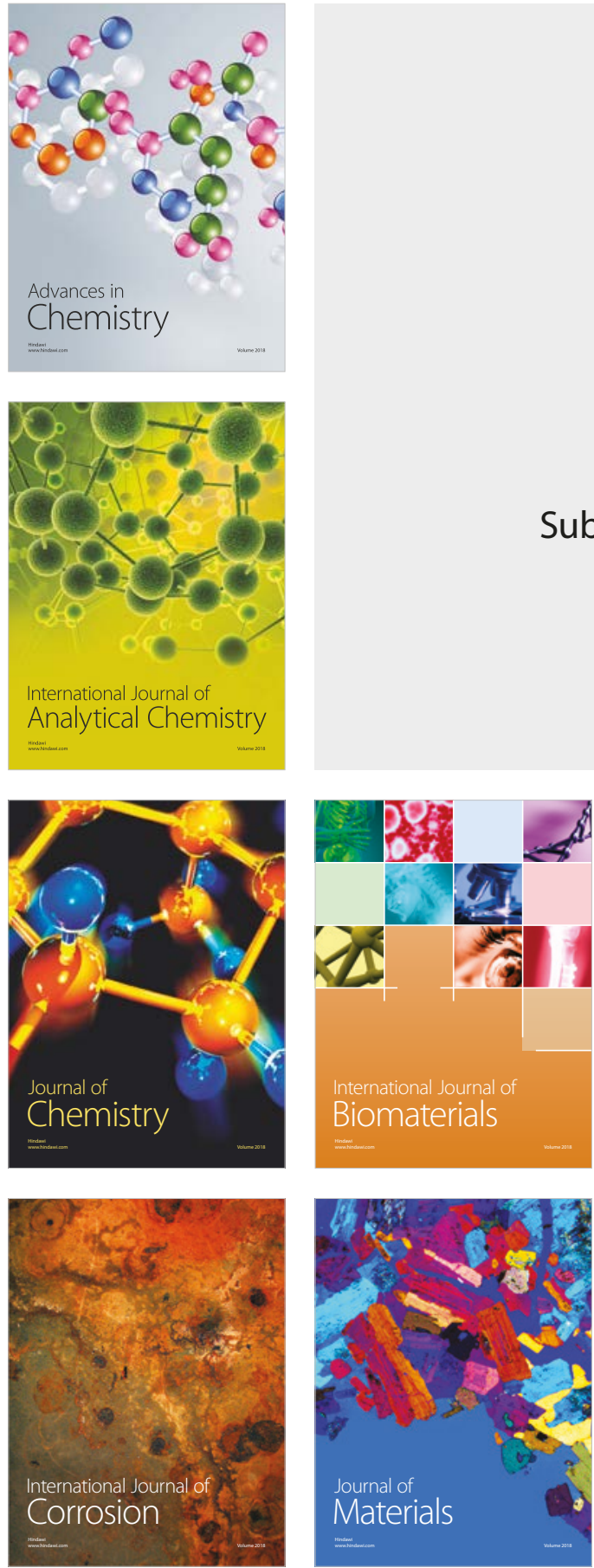

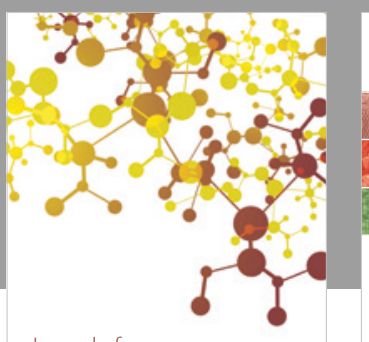

Journal of

Applied Chemistry
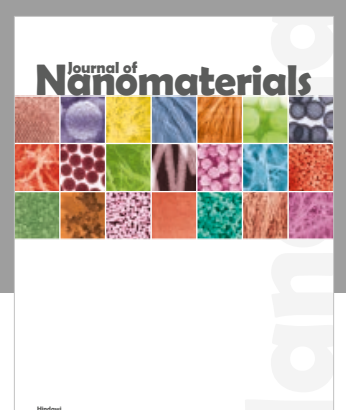

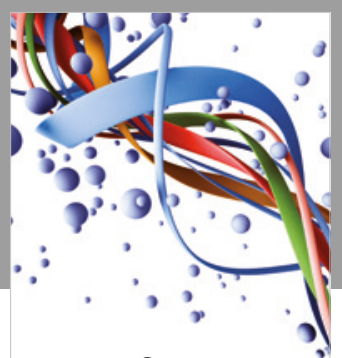

Scientifica

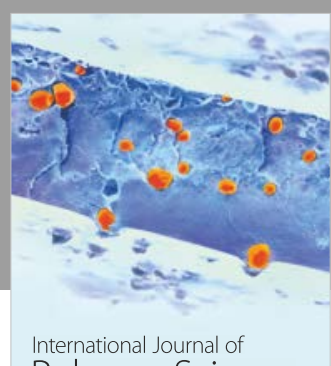

Polymer Science

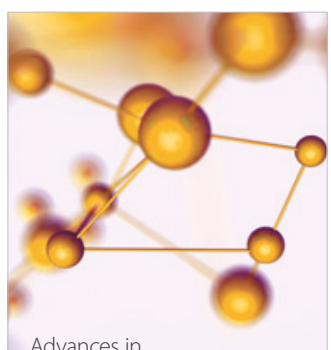

Physical Chemistry
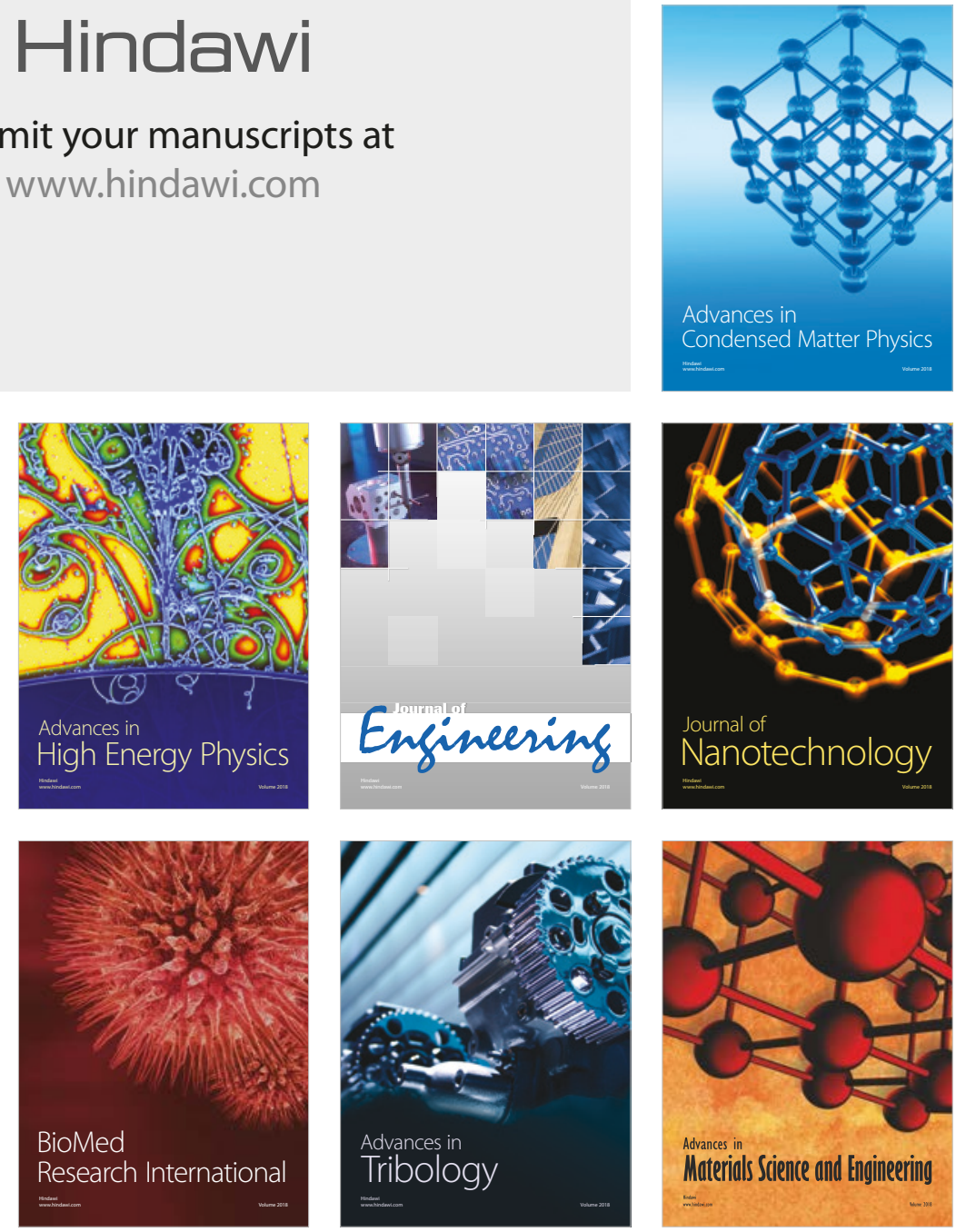